\title{
CONSTITUTIONALISATION OF PRIVATE LAW IN THE UNITED STATES OF AMERICA
}

Sebastian Kubas

$\Gamma$ he scope and application of the terms of the United States Con1 stitution to private conduct is generally perceived in the context of the so-called state action doctrine invented by the Supreme Court in the late $19^{\text {th }}$ century. It can be argued that, at first sight, the US Constitution is not applicable to relations between private individuals, the only exception being the Thirteenth Amendment which states that "[n]either slavery nor involuntary servitude (...) shall exist within the United States." This ban on slavery ratified in 1865 was clearly aimed for the "utter and complete extirpation" of slavery so not only was government-sanctioned slavery prohibited but also private types of domination. ${ }^{1}$

The main constitutional ground for the assessment of the Constitution's effectiveness among private persons is the Fourteenth Amendment which contains the following language in section 1: "No state shall make or enforce any law which shall abridge the privileges or immunities of citizens of the United States; nor shall any state deprive any person of life, liberty, or property, without due process of law; nor deny to any person within its jurisdiction the equal protection of the laws." The Federal Civil Rights Act of 1875 banned private racial discrimination but the Supreme Court in the Civil Rights Cases

\footnotetext{
A.R. Amar, America's Constitution. A Biography, New York 2006, pp. 358. 360 .
} 
(1883) found those provisions unconstitutional. The Court narrowly read the Fourteenth Amendment and declared that the first section of this Amendment, which was the one relied on in Congress, is prohibitory upon the States. "It is State action of a particular character that is prohibited. Individual invasion of individual right is not subject-matter of the amendment."2 As Erwin Chemerinsky puts it, "The Civil Rights Cases, in 1883 , are generally credited with mandating the requirement for state action. (...) The central holding of the Civil Righs Cases - that the Fourteenth Amendment applies only to the government, not to private conduct - remains the law and is a central principle of constitutional law."

The requirement or doctrine of state action is central to the applicability of the Constitution to private relations. According to this requirement, purely private behavior does not need to comply with the Constitution. This rule was reiterated many times by the Court for instance in the Shelley v. Kraemer decision where the Court explicitly articulated that since the Civil Rights Cases "the principle has become firmly embedded in our constitutional law that the action inhibited by the first section of the Fourteenth Amendment is only such action as may fairly be said to be that of the States. That Amendment erects no shield against merely private conduct, however discriminatory or wrongful." ${ }^{\prime 4}$ There were some earlier decisions before 1883 in which a similar approach was used. Chemerinsky points to United States v. Cruikshank (1875) where the Court said that the Fourteenth Amendment does not add anything to the rights which one citizen has under the Constitution against another. ${ }^{5}$ David $\mathrm{M}$. O'Brien quotes Ex Parte Virginia (1880), the case in which a Virginia judge was charged with violating federal law for excluding blacks from juries. The judge countered that because the state had no law

\footnotetext{
2109 U.S. 3 (1883).

3 E. Chemerinsky, Constitutional Law. Principles and Policies, New York 2006, pp. 507-508 (Aspen Treatise Series).

4334 U.S. 1 (1948).

5 E. Chemerinsky, "Rethinking State Action", Northwestern University Law Review, Vol. 80, No. 3 (Fall 1985), p. 507.
} 
excluding blacks from juries, his actions though official did not constitute "state action." It is however Justice Bradley's opinion in Civil Rights Cases that is used and discussed in dozens of Court's decision from the $19^{\text {th }}$ century till present. Naturally, the doctrine radiates to the whole judiciary. In 2008 Julie K. Brown wrote: “Lower courts are currently struggling with the state action doctrine not because of lack of guidance from the United States Supreme Court, but because the lower courts are under the heavy burden of weighing such a fact-dependent matter against the host of state action tests handed down by the Supreme Court."

Actually, as Francisco M. Ugarte stresses, the Civil Rights Cases, that were affirmed in United States v. Morrison in 2000, are among the few Jim Crow cases that remain good law. ${ }^{8}$ It should also be noted that this seminal decision from 1883 "fashioned a Fourteenth Amendment jurisprudence considerably less protective of individual rights than many of its framers had envisioned" and it also "largely mandated the withdrawal of the federal government from civil rights enforcement."' In fact, after the failure of the Civil Rights Act of 1875 Congress waited almost 90 years before it passed another major anti-discrimination piece of legislation, that is the Civil Rights Act of 1964, this time under the Commerce Clause.

As shown above, the dominant view of the Court is that the private infringements of constitutional rights are outside its jurisdiction. The state action doctrine requires that the wrongful conduct of private individuals has some connection to state authority to be actionable under the Fourteenth Amendment. Some kind of nexus to the state or entanglement must be shown to allow the Court to reach the

\footnotetext{
6 D.M. O'Brien, Constitutional Law and Politics, Vol. 2: Civil Rights and Civil Liberties, New York 2011, p. 1395.

7 J.K. B row n, "Less is More. Decluttering the State Action Doctrine", Missouri Law Review, Vol. 73, Issue 2 (Spring 2008), pp. 561, 572.

8 F.M. Ugarte, "Reconstruction Redux: Rehnquist, Morrison, and the Civil Rights Cases", Harvard Civil Rights - Civil Liberties Law Review, Vol. 41 (Summer 2006), p. 481 .

9 R.J. Cottrol, "Civil Rights Cases" in K.L. Hall (ed.). The Oxford Guide to United States Supreme Court Decisions, Oxford 2000, p. 56.
} 
merits of a case. This requirement refers to the government's activity at any level: the state level, but also the federal one. It is then the state/governmental involvement that makes the state responsible for the wrongful activity. If the state action is found the court orders the state only to disengage itself from the challenged activity so without the state's involvement the activity may be continued. ${ }^{10}$

The Court has stated and restated the state action doctrine many times. In Jackson v. Metropolitan Edison Co. (1974) ${ }^{11}$ the Court imposed a strict state action requirement on equal protection and due process claims. In this decision, because this requirement had not been met, the Court offered no remedy against a private utility that terminated electric service to a customer without prior notice. ${ }^{12}$ The Justices reminded that they had found state action present in the exercise by a private entity of powers traditionally exclusively reserved to the State. However, they rejected the petitioner's argument that a private utility like Metropolitan Edison Company performs public function, although it is heavily regulated and is enjoying at least a partial monopoly in the providing of electrical service within its territory. The majority of the Justices $(6: 3)$ decided that supplying of utility service is not traditionally the exclusive prerogative of the State.

Well-established usage of the state action doctrine caused its typical consolidation and a kind of reluctant veneration for it. In 1982 the Court (quoting Jackson v. Metropolitan Edison Co.) declared in Lugar v. Edmondson Oil Co. careful adherence to the state action requirement and remarked: "Whether this is good or bad policy, it is a fundamental fact of our political order."13

However, as it is usually the case with judicial inventions, the state action doctrine and the meaning of the Reconstruction Amend-

\footnotetext{
10 E. Chemerinsky, "Rethinking State Action", p. 541.

419 U.S. 345 (1974).

12 See also M.A. Graber, "Subtraction by Addition? The Thirteenth and Fourteenth Amendments", Columbia Law Review, Vol. 112, No. 7 (2012), p. 1505; H. Hershkoff, "Horizontality and the 'Spooky' Doctrines of American Law", Buffalo Law Review, Vol. 59 (2011), p. 504.

13457 U.S. $922(1982)$.
} 
ments has been neither uniformly understood nor consistently applied by the Justices. The notion of a "fact" is therefore rather exaggerated in this context. In the first 80 years the impact of the Justices' understanding of these Amendments was more far-reaching than later on. In the Civil Rights Cases opinion in 1883 the Court not only limited its own jurisdiction but also greatly limited the Congress's power to regulate private conduct under the Reconstruction Amendments (Amendments XIII, XIV and XV). The Court declared that the Thirteenth Amendment applies to private conduct but the Congress's power was limited to ensuring an end to slavery, that is to abolish "all badges and incidents of slavery." The federal legislation based on the Thirteenth Amendment could not go further and regulate acts of private discrimination. The Court adjudged that under the authority given by the Thirteenth Amendment the Congress could not adjust "the social rights of men and races in the community." As mentioned above, the Court also declared that the Fourteenth Amendment had not authorized the Congress to establish such regulations. In 1968 the Court changed its position on the Congress's powers. In Jones v. Alfred H. Mayer Co. (1968) the Court accepted the view that under the Thirteenth Amendment Congress is allowed to prohibit private racial discrimination. ${ }^{14}$ In recent years there has even been a renewed emphasis on the Thirteenth Amendment, "inspired, in part, by a sense that the Fourteenth Amendment may be a weaker reed for protecting fundamental rights. ${ }^{{ }^{15}}$ It should also be noted that one can argue the Jones decision is in serious tension with the more recent City of Boerne v. Flores (1997) decision that offers a substantially more restrictive standard for evaluating congressional legislation. ${ }^{16}$

14 See extended discussion in E. Chemerinsky, Constitutional Law, pp. 288 293.

is M.A. Graber, "Subtraction by Addition?...", p. 1505. In the conclusion of his paper M.A. Graber states that it is doubtful whether the Thirteenth Amendment revivalism has the potential to end the long period of racial stagnation in the United States.

${ }_{16}$ See J.M. Mc Award, "The Scope of Congress's Thirteenth Amendment Enforcement Power After City of Boerne v. Flores", Washington University Law Review, Vol. 88, Issue 1 (2010), p. 77. 
The state action doctrine was also given many new twists in the jurisprudence of the Court. All this is very well summarized by David M. O'Brien. In the 1940 s and 1950 s the Court took a leading role in the process of ending racial segregation. In an otherwise important decision, Shelley v. Kraemer (1948), the state action doctrine became, in the words of D.M. O'Brien, "a tool for the Court to reach and ban private racial discrimination." The significance of the doctrine was substantially weakened. For two decades after the Shelley decision the Court did not deny a relief because of the perceived absence of state action. Following Richard Nixon's win to the Presidency, Chief Justice Burger's Court and later Chief Justice Rehnquist's Court introduced many changes to the doctrine. The scope of it was narrowed which led to the enlargement of the range of private activities immune from suits under the Fourteenth Amendment. Generally the Court dismissed arguments for extending the doctrine of state action. ${ }^{17}$ An example of this approach is the Moose Lodge No. 107 v. Irvis (1972) decision. A guest of a private club, Moose Lodge, was refused service because of his skin color. He sought an injunction to revoke the club's license to sell liquor until it ceased its discriminatory practices. The state liquor license issued to the club was the plaintiff's argument that the state action requirement was satisfied. The Supreme Court reversed the district court's verdict and ruled against the black guest ("a Negro," as he was called in Justice Rehnquist's opinion). The Justices concluded that "Moose Lodge's refusal to serve food and beverages to a guest by reason of the fact that he was a Negro does not (...) violate the Fourteenth Amendment." According to the Justices there was no state action because there was no suggestion "that the Pennsylvania statutes and regulations governing the sale of liquor are intended either overtly or covertly to encourage discrimination." ${ }^{18}$ This way the racial discrimination issue was not discussed for the state action doctrine allowed the Court not to reach the merits of the case. In his critical assessment of this opinion

\footnotetext{
17 See O'Brien, Constitutional Law and Politics, Vol. 2, pp. $1397 \cdot 1406$.

18407 U.S. $16_{3}$ (1972).
} 
Odilon Castello Borges Neto aptly stated: "When the United States Supreme Court affirms that a private discriminatory policy may not be outlawed, it is indeed supporting such an invidious conduct, at least, indirectly." ${ }^{19}$

It is possible to discuss state action requirement as a purely legal doctrine and consider whether it is sufficiently grounded in the constitutional text or otherwise. To this Chemerinsky presents four answers. A textual justification of state action doctrine relies on the perception that the text of the U.S. Constitution "seems to limit its application to just the government." There are phrases like: "Congress shall make no law..." or "No state shall make or enforce any law..." that may be read as directed only to the government. A historical explanation lies with the common law. It was thought in the $18^{\text {th }}$ and $19^{\text {th }}$ century that individuals are protected from private infringements of their rights by the common law so no constitutional, horizontal protection was needed. Two policy rationales were also articulated by the Court. State action supposedly preserves an area of individual freedom and enhances federalism. ${ }^{20}$

In spite of these explanations - which will be discussed shortly below - there is an overarching theme that runs throughout the evolution of this doctrine. It can be called a theme of racial inequality or simply racism. The Justices of the Court used the state action doctrine as a convenient device in the process of taming of the Reconstruction Amendments. Lewis H. LaRue remarked, that these Civil War amendments brought the norm of equality into the Constitution, but in 1873 in Slaughterhouse Cases, the Supreme Court began to interpret equality back out of it and completed this process in 1896 in Plessy v. Ferguson. ${ }^{21}$ This was the infamous case in which the Court

19 O.C. Borges Neto, "Is the State Action Requirement Really Necessary? A Comparative Study Between the American and the Brazilian Systems of Fundamental Rights Protection", Revista Juridica Universidad de Puerto Rico, Vol. 75, No. 3 (2006), pp. $805,856$.

20 E. Chemerinsky, Constitutional Law. pp. 510-513.

21 L.H. La Rue, Constitutional Law as Fiction. Narrative in Rhetoric of Authority, University Park 1995, p. 120. 
supported racial segregation. The Court in fact devised a "catch-22" reading of federalism that helped to undo civil rights enforcement after the Civil War. Authors of The Supreme Court. An Essential History explain it this way. In Hall v. DeCuir (1877) the Court struck down a Louisiana statute barring racial segregation on its common carriers (trains, boats etc.). The majority of the Court found that the state could not regulate its waterways, for steamboat travel was interstate commerce, so only Congress could regulate it. This was the first prong of a very elegant tool. The second one was exposed in Civil Rights Cases: Congress could not act unless the offender was the state itself or its agents. "Thus private discrimination of all kinds must be left to the state to remedy. But the state could not legislate against those forms of discrimination touching interstate commerce because Congress had exclusive jurisdiction." 22 Francisco M. Ugarte has delivered a powerful argument that state action doctrine was grounded in racism and noted that $C$ ivil Rights Cases alongside Plessy v. Fergusson "were instrumental in the creation of a new legal regime that (...) established and perpetuated racial subordination throughout nearly all elements of American society. ${ }^{23}$ These maneuvers of the Court were actually largely applauded not only in the South. Since 1873 there was a feeling of general apathy towards Reconstruction and a growing impatience with the use of national authority to protect the colored race. When the Court invalidated the Civil Rights Act of 1875 (in Civil Rights Cases) the press almost uniformly cheered the Court's decision. ${ }^{24}$

The results of the doctrine were nothing short of remarkable. The courts tolerated the violation of virtually every constitutional value because of the absence of state action. ${ }^{25}$ In the year of 2000 Chief Justice Rehnquist in United States v. Morrison called it "the

22 P. Ch. Hoffer, W. Hoffer, N.E.H. Hull, The Supreme Court. An Essential History, Lawrence 2007, p. 142.

23 F.M. Ugarte, "Reconstruction Redux...", p. 484.

24 See B. Friedman, The Will of the People. How Public Opinion Has Influenced the Supreme Court and Shaped the Meaning of the Constitution, New York 2010, pp. 145-149.

${ }_{25}$ See E. Chemerins ky, "Rethinking State Action", p. 510. 
time-honored principle that the Fourteenth Amendment, by its very terms, prohibits only state action. ${ }^{26}$ It would be an understatement to say that this view and reverence for this "time honored principle" has not been universally shared. Charles L. Black, Jr famously excoriated the doctrine calling it "a conceptual disaster area" in 1967. Since he saw it as a doctrine without shape or line, he added that the whole thing - by which he meant the jurisprudence of the Court regarding this issue - "has the flavor of a torchless search for a way out of a damp echoing cave." 27 Black's bitter quip about a "conceptual disaster area" was repeated by many scholars who were unable to make any sense of the Supreme Court's endeavors in this field, at least in its legal dimension. In a more recent article Julie $\mathrm{K}$. Brown concluded that the current state of affairs requires decluttering the state action doctrine by the Supreme Court because it is "slowly descending into utter confusion where private parties remain unaware of what conduct subjects them to Constitutional restriction, and courts are unclear as to the appropriate state action standard. ${ }^{28}$

Much more clear is the sociopolitical context of relevance of the state action doctrine. In the 1940 , national civil rights consciousness crystallized in the United States. Many adhered to the view expressed in the words of a newspaper article of the time: "a nation that has poured out its blood and treasure in a war billed as a contest against racism can hardly afford the luxury of forcing its own citizens to live in ghettos." ${ }^{29}$ Mark A. Graber rightly observed that after that period, when an increased number of racial egalitarians gained political power during the third quarter of the $20^{\text {th }}$ century the majorities in the Supreme Court (under Chief Justice Vinson's and Chief Justice Warren's leadership) “consistently found state action in cir-

\footnotetext{
26529 U.S. 598 (2000).

27 Ch.L. Black Jr, "The Supreme Court 1966 Term - Foreword: 'State Action', Equal Protection, and Califormia Proposition 14", Hanvard Law Review, Vol. 81 (1967), p. 95 .

28 J.K. B rown, "Less is More...", p. 581.

29 M.J. Klarman, From Jim Crow to Civil Rights: the Supreme Court and the Struggle for Racial Equality, Oxford 2004, p. 215.
} 
cumstances where nineteenth-century justices saw only private racial discrimination." ${ }^{30}$ Later, however, the impetus behind the rights revolution dissipated and with Nixon's judicial appointments the conveniently fuzzy state action doctrine regained its prominence.

It should be firmly stated that the state action doctrine is a unique invention of the Justices of the Supreme Court. Its textual basis is weak. The Fourteenth Amendment does not contain a threshold requirement of demonstrating "state action," absence of which makes legal all private infringements of fundamental rights. Chemerinsky advances a convincing argument that this is a misinterpretation of the Fourteenth Amendment for the key issue is whether a state deprived someone of a guaranteed right. If a state fails to stop private violations of liberty and equality or denies redress for violations, a state denies and deprives its citizens of rights and equality. ${ }^{31}$. Historically speaking, argues David P. Currie, a strong argument can be made, on the basis of the origins of the equal protection clause, that private lynching was among the evils that Congress was meant to have power to forbid. The very failure of the states to protect blacks prompted the adoption of the Fourteenth Amendment. ${ }^{32}$ Justice John Marshall Harlan, the lone dissenter in the Civil Rights Cases, correctly decried the majority's narrow reading of this Amendment with the words: "The substance and spirit of the recent amendments of the Constitution have been sacrificed by a subtle and ingenious verbal criticism." ${ }^{33}$ In fact, as a Polish scholar, Marek Piechowiak noted, the state action requirement is a kind of legal fiction. The Supreme Court firstly balances the competing rights and only then if the result is in favor of the petitioner, does it decide the Court decides that the violator's action satisfies the state action requirement. ${ }^{34}$ Cass $R$. Sun-

\footnotetext{
30 M.A. Graber, "Subtraction by Addition?...", pp. 1544-1545.

31 See E. Chemerinsky, "Rethinking State Action", pp. 520-522.

32 D.P. Currie, The Constitution in the Supreme Court: The First Hundred Years, 1789-1888, Chicago 1985, p. 397.

33109 U.S. 3 (1883).

${ }^{34}$ M. Piechowiak, Filozofia praw człowieka. Prawa czlowieka w świetle ich miedzynarodowej ochrony (Philosophy of Human Rights: Human Rights in the
} 
stein makes a similar claim in saying that state action is always present and the real question involves the meaning of the relevant constitutional guarantees. ${ }^{35}$ Elsewhere, this author takes his argument further by observing that the state action inquiry is not a search for whether the state has "acted, " but it is "an examination of whether it has deviated from functions that are perceived as normal and desirable under the relevant constitutional provision. ${ }^{36}$

The traditional common law explanation is no longer valid and was not really valid in the $19^{\text {th }}$ century when the Civil War Amendments were adopted. In the era of racial segregation the civil rights of black Americans were not protected by common law. Nowadays, the protection offered by common law seems to be inadequate, especially in the era of the Internet and the ubiquity of social media.

Amid the criticism of the state action doctrine Stephen Gardbaum's argument stands out and sheds light not only on the issue whether private actions are subject to constitutional constraints. His reasoning illuminates also, more generally, the problem of the horizontal effect of constitutional rights in countries that do not adopt the doctrine (or rather "anti-doctrine") of state action. A very short summary of Gardbaum's argument runs as follows. The axiom of the state action doctrine does not resolve the issue of defining the scope of application of constitutional rights. The answer lies in the Supremacy Clause which renders all law directly subject to the Constitution. Private actors are not directly bound by the Constitution but individual rights provisions govern their legal relations with each other. Whenever the constitutionality of a law invoked in litigation between private actors is challenged, there should be no threshold issue of state action. There is just the substantive issue of whether

Light of their Intermational Protection], Lublin 1999, p. 160 (Prace Wydziatu Filozoficznego / Towarzystwo Nukowe KUL, 81).

35 See C.R. Sunstein, "State Action is Always Present", Chicago Joumal of International Law, Vol. 3, No. 2 (Fall 2002), p. 465.

36 Idem, The Partial Constitution, Cambridge 1993, p. 74. 
that law violates the Constitution. ${ }^{37}$ Private actors are unable to rely on an unconstitutional law in any ordinary, nonconstitutional cause of action. However, and by contrast, there can be no constitutional cause of action against a private actor for breach of a constitutional duty, because private actors have none. Actions by private actors are immune from constitutional scrutiny only if they do not rely on any law or if the victim has no relevant cause of action..$^{38}$ An example is given of a black beggar that has no common law tort or statutory cause of action to challenge the property law of a racist donor who gives change only to white beggars. Let us consider another example: breach of promise. Common law action for breach of a promise to marry was used from the $17^{\text {th }}$ century, predominantly by women. Since the 1930 s many states, but not all of them, have enacted statutes that abolished this type of action. In light of Gardbaum's thesis, one can argue that in those American jurisdictions which retain the breach of promise action it would be possible to invoke constitutional rights during proceedings before a court of law although plaintiff and defendant are private persons. Yet, in those states that do not allow a lawsuit to be brought for a breach of promise, no constitutional reservations concerning this private issue can be raised. Since a supremacy clause is usually found in many modern constitutions, it is indeed promising to analyze this way a given country's position on the scope of constitutional rights and their impact on private actors. According to Gardbaum's analysis the United States take no less a horizontal position than Germany, for in both countries constitutional rights directly govern all private law and so indirectly govern private actors. ${ }^{39}$

I have emphasized here the connection between the state action doctrine and racial inequality. Racial segregation and discrim-

37 S. Gardbaum, "The 'Horizontal Effec' of Constitutional Rights", Michigan Law Review, Vol. 102 (December 2003), Pp. 390-391.

38 Ibid., Pp. 420.422.

39 Idem, "The Myth and the Reality of American Constitutional Exceptionalism", Michigan Law Review. Vol. 107, No. 3 (December 2008), p. 437. 
ination was facilitated and promoted by the Supreme Court's decisions. Over the last few decades the state action doctrine has taken on a new significance in the Internet era. Major Internet companies are U.S.-based and privately held. They provide services for billions of consumers worldwide. The traditional way of thinking tied to the axiom of state action makes this ever-growing sphere of interactions immune from constitutional scrutiny. Paul Schiff Berman warned, as early as in 2000 , that all of cyberspace may become an effectively private, Constitution-free zone. ${ }^{40}$ The same term was used in 2014 by Benjamin F. Jackson who wrote that social network websites are "essentially Constitution-free zones where the threat of censorship, both overt and subtle, looms large." The reason for this is the state action doctrine that causes a lack of constitutional protection of communications on social network websites. ${ }^{41}$

At least three general conclusions come to mind, none of which are particularly reassuring. First, the state action doctrine creates considerable problems both in the judiciary and the academy. It is because serious challenges of civil rights abuses in a modern state are tackled with $19^{\text {th }}$-century doctrine grounded in racism that was devised as an answer to a seismic shift in the U.S. legal system following the Civil War. This approach seems to be wrong or at least strikingly outdated.

Second, struggles with regard to the state action requirement show, in a more methodological register, how an unwise and pernicious doctrine may obscure the dilemmas of justice that courts and scholars face. The importance attached to this doctrine requires that the rights of a private violator should always be favored over the rights of a private victim. Let us consider the acerbic words of Erwin Chemerinsky who in 1985 reminded that during the 1950 s and

40 See P.S. Berman, "Cyberspace and the State Action Debate: The Cultural Value of Applying Constitutional Norms to 'Private' Regulation", University of Colorado Law Review, Vol. 71, No. 4 (May 2000), p. 1263.

${ }^{4}$ B.F. Jacks on, "Censorship and Freedom of Expression in the Age of Facebook", New Mexico Law Review, Vol. 44, No. 1 (Spring 2014). p. 166. 
1960 state action had attracted probably the most attention in law review articles. Some years later this attention largely disappeared. In Chemerinsky's opinion, earlier commentators were successful in demonstrating the incoherence of the state action doctrine and in arguing that this concept could never be rationally or consistently applied. Despite the criticism, the Supreme Court steadfastly enforced its requirement of state action. Thus, explains Chemerinsky, "there was seemingly no direction for scholarship about state action; making sense of the concept of state action was perceived as impossible, and arguing for its elimination was considered futile." ${ }^{42}$ This pow. erful critique of the Court has lost none of its relevance and force. The state action doctrine still hampers the systematic protection of constitutional rights.

Third, there is a lesson to be leamed from the way the scope of constitutional rights is understood in the United States. The inability of American courts to sufficiently protect constitutional rights against private intrusions raises the question of the real role of the rights enshrined in the Constitution. One answer may be that they should protect individual autonomy. In that case it does not matter who the violator is and it is nonsensical to require a finding of state action. This means that at least the indirect horizontal effect of constitutional rights must be accepted. I share the view expressed by Monika Florczak-Wątor that in a modern democratic state the conduct of private actors may be the biggest threat to constitutional rights and liberties; therefore a horizontal effect of constitutional rights is indispensable to their protection. ${ }^{43}$ Another answer is that constitutional rights are only a kind of constitutional badge of decency. They apply only to limit the government, whereas nongovernmental violations of individual rights may well be tolerated. The second answer fits precisely the U.S. position and it partially explains why the United States

\footnotetext{
42 E. Chemerinsky, "Rethinking State Action", pp. 504-505.

43 M. Florczak-Wątor. Horyzontalny uymiar praw konstytucyjnych ('Horizontal Dimension of Constitutional Rights'), Kraków 2014. p. 417.
} 
is increasingly out of sync with an evolving global consensus on issues of human rights. ${ }^{44}$

\section{STRESZCZENIE}

Powszechna i obowiązująca poprzez orzecznictwo Sądu Najwyższego interpretacja Konstytucji USA opiera się na tezie, że zasadniczo akt ten nie reguluje relacji pomiędzy podmiotami prywatnymi. Istotnym wyjątkiem jest Trzynasta Poprawka, która zakazuje całkowicie niewolnictwa, także w relacjach prywatnych. Główną konstytucyiną normą stosowaną do oceny skuteczności norm konstytucyjnych w relacjach między podmiotami prywatnymi jest Czternasta Poprawka, nakazująca m.in. prawidłowe stosowanie prawa (due proces of law) oraz równą ochronę prawną. Od 1883 r. Sąd Najwyższy rozwija na tle tego przepisu doktrynę state action, przez pryzmat której ocenia się skuteczność norm konstytucyjnych względem podmiotów prywatnych.

Doktryna ta oznacza, że zachowanie o całkowicie prywatnym charakterze nie podlega ocenie sądów względem zgodności z Konstytucją. Podmioty prywatne powołujące się na naruszenie ich konstytucyjnych praw mogą domagać się ochrony sądowej wyłącznie w przypadku wykazania, że spełniony jest wymóg state action, działania władz. Prywatne naruszenia praw konstytucyjnych mogą wywołać reakcję sądową, jeśli powodowi uda się wykazać, że dokonywane są one przy współdziałaniu władz państwowych (na dowolnym poziomie, w szczególności władz stanowych lub federalnych). Sąd Najwyższy wyraźnie formułuje w swym orzecznictwie tezę, że Konstytucja nie chroni przed czysto prywatnymi zachowaniami naruszającymi prawa konstytucyjne, w tym przed prywatną dyskryminacją.

Doktryna state action jest wytworem Sądu Najwyższego, który w ten sposób sprzeciwiał się zmianom w prawie dokonanym w następstwie wojny secesyjnej. Zasadnie można twierdzić, że doktryna ta ma rasistowską genezę, a rozwijający ją sędziowie Sądu Najwyższego stworzyli podstawy

\footnotetext{
44 See extended discussion of whether (and why) the United States is a constitutional outlier in D.S. Law, M. Versteeg, "The Declining Influence of the United States Constitution", New York University Law Review, Vol. 87, No. 3 (June 2012), p. 762 .
} 
prawne dla obowiązującego do połowy XX w. systemu segregacji rasowej. Doktryna state action jest wyjątkowym, bo nadal obowiązującym, reliktem rasistowskiej interpretacji Konstytucji. Jej podstawa normatywna jest nad wyraz wąłła, tekst Konstytucji nie wprowadza wymogu wykazania działania władz na potrzeby ochrony praw konstytucyjnych. Interpretacja historyczna prowadzi raczej do tezy, że twórcy Czternastej Poprawki pragnęli zapobiec prywatnym naruszeniom prawa, takim jak lincze na ludności czarnej.

W kolejnych dekadach rozumienie doktryny state action zależało od postawy ideologicznej większości sędziów Sądu Najwyższego. W latach 40. i 50. straciła ona na znaczeniu, Sąd Najwyższy reagował na nanuszenia praw konstytucyjnych, ale od prezydentury Richarda Nixona przewage w Sądzie zyskali przeciwnicy egzekwowania Konstytucji w relacjach prywatnych. Wymóg wykazania działania władz jest bardzo dogodnym narzędziem, za pośrednictwem którego sędziowie uchylają się od oceny naruszeń praw konstytucyjnych, toteż doktryna state action ponownie stała się poglądem ustrojowym o podstawowym znaczeniu. Po dziś dzień stanowi ona skuteczną barierę przed stosowaniem Konstytucji w relacjach prywatnych. Jednocześnie trzeba podkreślić, ze ta wychwalana w orzecznictwie Sądu doktryna jest niezwykle krytycznie oceniana przez wielu przenikliwych badaczy prawa amerykańskiego, takich jak Erwin Chemerinsky, Cass R. Sunstein czy Stephen Gardbaum. Uważa się ją za nobszar klęski pojęciowej", nie sposób bowiem racjonalnie przedstawić jej treści. Przez wiele lat $w$ drugiej połowie XX w. doktryna ta uważana była za naczelny problem w amerykańskim prawie konstytucyjnym, ale wobec nieugiętej postawy Sądu Najwyższego zainteresowanie tym zagadnieniem osłabło, uznano bowiem, że nie można nadać tej doktrynie spójności ani wskazać, w jaki sposób można ją konsekwentnie stosować.

W ramach akademickich prób zwalczania doktryny state action przytoczyć można skrótowo pogląd C.R. Sunsteina, według którego wymóg działania państwa jest $w$ kontekście ochrony praw konstytucyjnych zawsze spełniony, a także rozbudowaną koncepcję S. Gardbauma, który wykazuje, że właściwa interpretacja amerykańskiej Konstytucji powinna opierać się na klauzuli jej nadrzędności. Skoro wszystkie przepisy obowiązujące w systemie prawnym USA podlegają ocenie co do zgodności z Konstytucją, jeśli w postępowaniu o ochronę praw konstytucyjnych przed prywatnym 
naruszeniem, podniesiony zostanie zarzut, że pozwalające na takie naruszenie przepisy są niezgodne z Konstytucją, sądy nie powinny, zdaniem S. Gardbauma, domagać się spełnienia wymogu działania państwa, ale merytorycznie oceniać zaskarżone przepisy. W tej alternatywnej koncepcji, w Stanach Zjednoczonych mówić należy o pośredniej horyzontalnej skuteczności praw konstytucyjnych.

Współcześnie doktryna state action nabiera nowego znaczenia w erze Internetu. Ponieważ główne przedsiębiorstwa internetowe, dostarczające usługi dla miliardów użytkowników na całym świecie, są przedsiębiorstwami prywatnymi, trafnie stwierdza się, że z powodu tej doktryny Internet jest strefą wolną od Konstytucji.

W podsumowaniu można wyrazić trzy tezy. Doktryna state action wywołuje zasadnicze problemy w orzecznictwie i sferach akademickich, ponieważ naruszenia praw człowieka w państwie współczesnym ocenia się według rasistowskiej koncepcji stworzonej przez Sąd Najwyższy w XIX w. Ponadto, doświadczenia $\mathrm{z}$ doktryną state action pokazują, jak szkodliwe poglądy zrodzone w orzecznictwie mogą skutecznie utrudniać ochronę praw konstytucyjnych.

$\mathrm{Na}$ tle rozumienia zakresu praw konstytucyjnych w Stanach Zjednoczonych i wycofania się sądów $z$ ochrony praw przed naruszeniami prywatnymi, można wreszcie postawić pytanie o to, jaka jest rzeczywista rola praw konstytucyjnych. W przypadku uznania, że mają one chronić autonomię jednostki, nie ma znaczenia, kto dokonuje naruszeń takich praw, więc należy zaakceptować co najmniej pośrednią horyzontalną skuteczność praw konstytucyjnych. Odpowiedź na to pytanie udzielana przez amerykański Sąd Najwyższy, sugeruje, że prawa konstytucyjne są jedynie oznaką przyzwoitości - ograniczają one działania władz, ale naruszenia praw przez podmioty niepaństwowe są tolerowane.

\section{BIBLIOGRAPHY}

Amar A.R., America's Constitution. A Biography, New York 2006.

Berman P.S., "Cyberspace and the State Action Debate: The Cultural Value of Applying Constitutional Norms to 'Private' Regulation", University of Colorado Law Review, Vol. 71, No. 4 (May 2000). 
Black Ch.L. Jr, "The Supreme Court 1966 Term - Foreword: 'State Action', Equal Protection, and California Proposition 14", Harvard Law Review, Vol. 81 (1967).

Borges Neto O.C., "Is the State Action Requirement Really Necessary? A Comparative Study Between the American and the Brazilian Systems of Fundamental Rights Protection", Revista Juridica Universidad de Puerto Rico, Vol. 75, No. 3 (2006).

Brown J.K., "Less is More. Decluttering the State Action Doctrine", Missouri Law Review, Vol. 73, Issue 2 (Spring 2008).

Chemerinsky E., "Rethinking State Action", Northwestern University Law Review, Vol. 80, No. 3 (Fall 1985).

Chemerinsky E., Constitutional Law. Principles and Policies, New York 2006 (Aspen Treatise Series).

Cottrol R.J., "Civil Rights Cases" in K.L. Hall (ed.). The Oxford Guide to United States Supreme Court Decisions, Oxford 2000.

Currie D.P., The Constitution in the Supreme Court: The First Hundred Years, $1789-1888$, Chicago 1985.

FLORCZAK-WĄTOR M., Horyzontalny wymiar praw konstytucyjnych ('Horizontal Dimension of Constitutional Rights'), Kraków 2014.

Friedman B., The Will of the People. How Public Opinion Has Influenced the Supreme Court and Shaped the Meaning of the Constitution, New York 2010.

Gardbaum S., "The 'Horizontal Effec' of Constitutional Rights", Michigan Law Review, Vol. 102 (December 2003).

Gardbaum S., "The Myth and the Reality of American Constitutional Exceptionalism", Michigan Law Review, Vol. 107, No. 3 (December 2008). Graber M.A., "Subtraction by Addition? The Thirteenth and Fourteenth Amendments", Columbia Law Review, Vol. 112, No. 7 (2012).

Hershroff H., "Horizontality and the 'Spooky' Doctrines of American Law", Buffalo Law Review, Vol. 59 (2011).

Hoffer P.Ch., Hoffer W., Hull N.E.H., The Supreme Court. An Essential History, Lawrence 2007.

JaCkson B.F., "Censorship and Freedom of Expression in the Age of Facebook", New Mexico Law Review, Vol. 44, No. 1 (Spring 2014).

Klarman M.J., From Jim Crow to Civil Rights: the Supreme Court and the Struggle for Racial Equality, Oxford 2004. 
LARUe L.H., Constitutional Law as Fiction. Narrative in Rhetoric of Authority, University Park 1995.

Law D.S., Verstefg M., "The Declining Influence of the United States Constitution", New York University Law Review, Vol. 87, No. 3 (June 2012).

McAward J.M., "The Scope of Congress's Thirteenth Amendment Enforcement Power After City of Boerne v. Flores", Washington University Law Review, Vol. 88, Issue 1 (2010).

O'Brifn D.M., Constitutional Law and Politics, Vol. 2: Civil Rights and Civil Liberties, New York 2011.

Pifchowiak M., Filozofia praw człowieka. Prawa człowieka w swietle ich międzynarodowej ochrony [Philosophy of Human Rights: Human Rights in the Light of their International Protection], Lublin 1999 (Prace Wydziatu Filozoficznego / Towarzystwo Nukowe KUL, 81).

Sunstein C.R., "State Action is Always Present", Chicago Joumal of International Law, Vol. 3, No. 2 (Fall 2002).

Ugarte F.M., "Reconstruction Redux: Rehnquist, Morrison, and the Civil Rights Cases", Hanvard Civil Rights - Civil Liberties Law Review, Vol. 41 (Summer 2006). 
